\title{
Bacterial Transfer Associated with Blowing Out Candles on a Birthday Cake
}

\author{
Paul Dawson ${ }^{1}$, Inyee Han ${ }^{1}$, Danielle Lynn ${ }^{1}$, Jenevieve Lackey ${ }^{1}$, Johnson Baker ${ }^{1} \&$ Rose Martinez-Dawson ${ }^{2}$ \\ ${ }^{1}$ Department of Food, Nutrition and Packaging Sciences, ${ }^{2}$ Department of Mathematical Sciences, Clemson \\ University, Clemson, SC 29634, USA \\ Correspondence: Paul Dawson, Depertment of Food, Nutrition and Packaging Sciences, Clemson University, \\ Clemson, SC 29634, USA. Tel: 1-864-656-1138. E-mail: pdawson@ clemson.edu
}

\author{
Received: March 24, $2017 \quad$ Accepted: April 10, $2017 \quad$ Online Published: May 22, 2017 \\ doi:10.5539/jfr.v6n4p1 \\ URL: https://doi.org/10.5539/jfr.v6n4p1
}

\begin{abstract}
This study examined the potential spread of bacteria when blowing out candles on a birthday cake. Preliminary tests of blowing on nutrient agar indicated that bioaerosols in human breath expelled from the mouth may be a source of bacteria transferred to cake surfaces. To test aerosol transfer to cake, icing was spread evenly over foil then birthday candles were placed through the foil into a Styrofoam ${ }^{\mathrm{TM}}$ base. After consuming pizza, test subjects were asked to extinguish the candles by blowing. Icing samples were sterilely recovered then surface plated, to determine the level of bacterial contamination. Blowing out the candles over the icing surface resulted in $1400 \%$ more bacteria compared to icing not blown on. Due to the transfer of oral bacteria to icing by blowing out birthday candles, the transfer of bacteria and other microorganisms from the respiratory tract of a person blowing out candles to food consumed by others is likely.
\end{abstract}

Keywords: birthday candles, aerosolized bacteria, blowing, bacterial transfer

\section{Introduction}

\subsection{Blowing Out Birthday Candles}

The tradition of blowing out birthday candles has different theories as to its origin. Some theorize the practice began in Ancient Greece related to bringing cakes with lit candles to the temple of the goddess of the hunt, Artemis. Other ancient cultures believed the smoke from candles carried their wishes and prayers to the gods. A written account reported of birthday candles matching the age of Count Ludwig Von Zinzendorf being presented at the Count's birthday celebration in Germany in 1700's (Frey, 1753). This tradition has become commonplace in many parts of the world.

\subsection{Spread of Bacteria}

Bacteria are an unavoidable part of life, present in and on almost everything humans contact. Whether benign or pathogenic, it is important to understand how bacteria are transferred and become familiar with measures for avoiding contamination. Illnesses related to pathogenic bacteria, which can spread rapidly throughout the population, are a major public health concern in today's society. Bioaerosols and poor air hygiene can have adverse effects on human health (Douwes, Thorne, Pearce \& Heederik., 2003; Xu et al., 2011). Respiratory droplets expelled by coughing and sneezing are sources of normal human flora, as well as pathogenic bacteria (Obeng, 2008; 1970; Houk, 1980) and viruses (Loosli, Hertweck, \& Hockwald, 1970). The respiratory tract can be colonized with pathogenic organisms that can then be aerosolized in the breath of an infected individual (Couch, Knight, Gerone, Cate, Douglas, 1969; Knight, 1973). The spread of respiratory diseases including SARS (Yu et al., 2004) and H1N1 avian influenza (Baker et al., 2010) have been attributed to oral airborne transmission. In fact, influenza virus particles were detected in the exhaled breath of infected individuals through coughing, breathing and talking (Fabian et al., 2008; Stelzer-Braid et al., 2009; Huynh, Oliver, Stelzer, Rawlinson \& Tovey, 2008; Lindsley et al., 2010). When respiratory droplets are released, they may spread infection directly from person-to-person or by contamination of surfaces then touched by others (Obeng, 2008). The bacteria may have originated from either respiratory droplets expelled directly onto surfaces or indirectly as droplets coating hands that are transferred by hands to surfaces. In fact, exhaled breath contained 693 to $6,293 \mathrm{CFU}$ of bacteria/m $\mathrm{m}^{3}(\mathrm{Xu}$ et al., 2012) and Qian, Hospodsky, Yamamoto, Nazaroff \& Peccia, (2012) reported that human occupants are 
significant contributors to indoor air bacteria and that humans emit bacteria at a rate of about 37 million gene copies per person per hour. Thus when a person forcibly exhales, as with blowing out birthday candles, bacteria or viral particles are aerosolized from the respiratory tract of that individual.

\subsection{Research Objective}

The purpose of this research was to evaluate the level of bacterial transfer transferred to the top of a cake when blowing out the candles on a birthday cake. Scientific data from our investigation may help raise awareness of possible health risks associated with birthday celebrations and encourage others to take steps toward preventing the spread of bacteria.

\section{Methods}

\subsection{Blowing Out Candles}

A sheet of foil (Bakers \& Chefs, Bentonville, AR) cut in the shape of a circle with a diameter of $149 \mathrm{~mm}$ placed on a Styrofoam ${ }^{\mathrm{TM}}$ disc (Styrofoam Brand Foam, Floracraft, Ludington, MI), of the same size then $18 \mathrm{~g}$ of icing (Betty Crocker Rich \& Creamy Vanilla Frosting, General Mills, Minneapolis, MN) was spread in a thin layer on the foil. Seventeen candles (Best Occasions, Bentonville, AR) $(3.2 \mathrm{~mm}$ in diameter, $50.8 \mathrm{~mm}$ high, and set in plastic holders $19.0 \mathrm{~mm}$ high) were evenly spaced into the Styrofoam, passing through the icing and foil layers. Each test subject was asked to smell and consume a piece of hot pizza to simulate a meal-dessert sequence. After lighting the candles, test subjects were instructed to blow until all of the candles were extinguished on the mock cake (Figure 1). For each testing session a control sample was collected where the procedure was followed for the test sample except candles were not blown out.

\subsection{Enumeration of Bacteria}

After lit candles were blown out (blow) or not blown out (no-blow) the candles and holders were removed from the Styrofoam ${ }^{\mathrm{TM}}$ base, without touching the icing. Using sterile forceps, the foil was folded in half with the layer of icing inside. Then, the foil was placed in a stomacher bag (Classic 400, Seward, UK) and unfolded inside the bag.

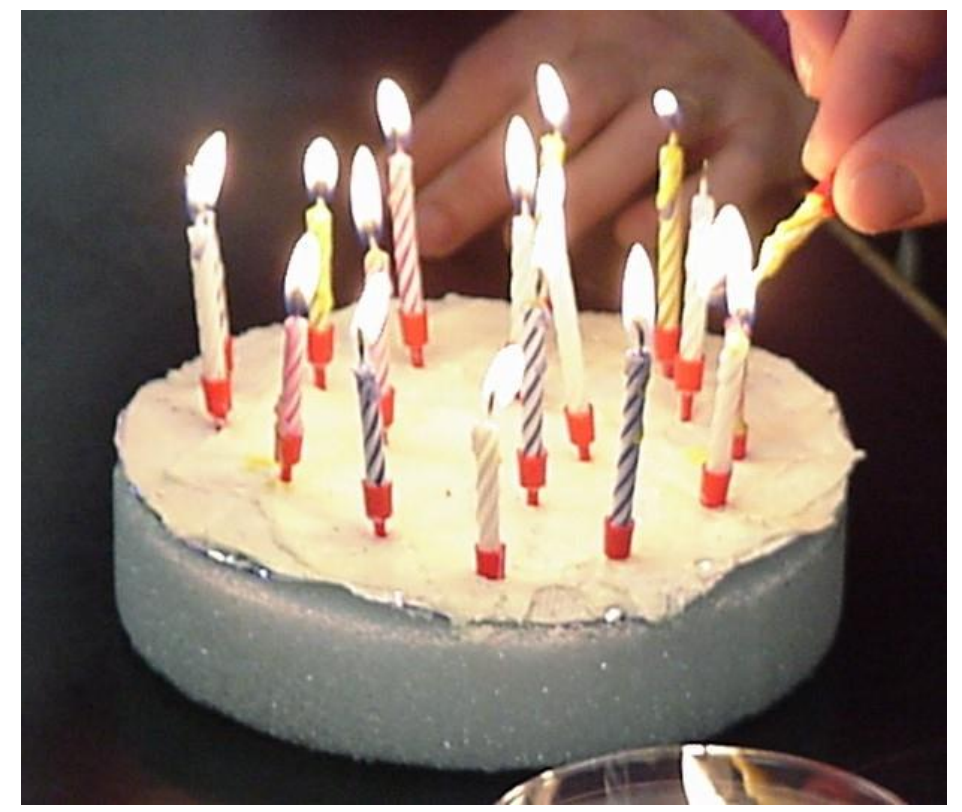

Figure 1. Styrofoam ${ }^{\mathrm{TM}}$ base and candle apparatus with icing used to test bacterial transfer when blowing out candles

Fifty $\mathrm{ml}$ of $0.1 \%$ sterile peptone solution were poured into the stomacher bag over the iced surface of the foil. The stomacher bag was placed in a stomacher (Stomacher 400, Seward, UK) at $230 \mathrm{rpm}$ for $1 \mathrm{~min}$. Duplicate samples of $1 \mathrm{ml}$ and $0.1 \mathrm{ml}$ volumes were aseptically removed from the stomacher bag (Classic 400, Seward, UK), serially diluted and surface plated on plate count agar (Difco Plate Count Agar, Sparks, MD) in petri dishes. Samples were spread evenly on the agar and incubated at $37^{\circ} \mathrm{C}$ for 48 hours. Colony forming units (CFU) were counted on plates containing $25-250$ colonies and converted to CFU per sample and $\log _{10}$ of CFU per sample. 


\subsection{Research Design and Statistical Analysis}

The experiment was replicated 3 times on separate days by 11 subjects yielding 33 observations per treatment (blow or no blow). The effect of blowing vs. not blowing candles out on bacterial counts in the frosting was determined using the proc univariate command of SAS (2010) to obtain mean, median, range and standard deviation. The student's t-test was also performed and proc glm and pdiff commands were used to determine if significant differences existed between the blowing and non-blowing treatments.

\section{Results and Discussion}

Blowing out candles over icing resulted in 15 times more and statistically higher number of bacteria recovered from icing compared to icing that did not have candles blown out (Table 1). Also, the variation (range) in bacteria recovered from icing was 100 times greater for icing exposed to the blow compared to the no blow treatment. Furthermore, the median and maximum transfer of bacteria increased 300 and 12,000\%, respectively, due to blowing out candles. Studies on airborne droplet size from the oral cavity are found as early as 1899 (Flugge, 1899) and by several others before the mid 20 ${ }^{\text {th }}$ century (Hutchison, 1901; Winslow, 1910; Strausz, 1922; Lange \& Nowoselsky, 1925; Hamburger, 1944; Duguid, 1946). These early studies came to varying conclusions but found droplets were released into the atmosphere surrounding humans that are breathing, coughing and sneezing. One study reported that $90 \%$ of bacteria-carrying droplets remaining airborne for 30 minutes in still air and that some smaller droplets remained for up to 30 hours (Duquid, 1946). More recently, Wan et al. (2014) established that up to over 2,000 moisture particles were released per breath, all less than 5 um in diameter. The particle size is an important factor since bioaerosols will carry both bacteria and viruses in small particle droplets generated by breathing, blowing and coughing. The average size of expelled particles generated by couching and speaking was found to be much larger (13.5 um for coughing and 16.0 um diameter for speaking) by measurement at the mouth opening thus minimizing the effect of evaporation on droplet (particle) size (Chao et al., 2008) which may be a factor in other studies using droplet condensation methodology. Chao et al. (2008) also found that there were between 1000 to 2000 in number and 2 to $5 \mathrm{ml}$ in volume of droplets per cough and even $0.2 \mathrm{ml}$ of moisture droplets during speaking. Therefore the size of droplets in expelled air are large enough to carry bacteria as well as viruses. Normal respiratory aerosols can include Staphylococcus spp., Streptococcus spp., Corynebacterium spp., Haemophilus spp., and Neisseria spp. (Madigan, Martinko, Dunlap, \& Clark, 2009). Madigan et al. (2009) also found certain pathogenic species, such as Streptococcus pneumonia and Staphylococcus aureus, may cause illness when spread through surface contamination via oral aerosols. Considering contagious diseases such as influenza, some researchers have concluded that airborne transmission is a likely pathway (Weder \& Stilianakis, 2008; Wein \& Atkinson, 2009). Fabian et al. (2008) and Stelzer-Braid et al. (2009) detected viral influenza in the exhaled breath of infected patients. To this point, Fabian et al. (2008) reported that $60 \%$ of patients with influenza $A$ had detectable levels of the virus in exhaled breath with $87 \%$ of exhaled particles less than 1 um in diameter. In another study, Lindsley et al. (2010) reported that $81 \%$ of influenza patients had influenza RNA in their breath and that $65 \%$ of the influenza were found in aerosol particles 4 um in diameter or smaller.

Verifying that bacterial cells as well as viruses are carried on human bioaerosols, Fennelly et al (2004) reported that 25\% of tuberculosis patients exhaled from 3-633 CFU per cough of Mycobacterium tuberlosis in expelled air particles.

Birthday celebrations routinely include the ceremonial blowing out of candles on top of a cake. Some food safety concern exists in light of previous research on bioaerosols generated by breathing, coughing and speaking supported by the results of the present study finding that bacterial levels averaged 15 times higher in icing due to blowing out candles.

Table 1. Mean, median, range and standard deviation of the bacterial counts for cake icing exposed to blowing out candles and not blowing out candles

\begin{tabular}{lcccc}
\hline & No blow $^{1}$ & Blow $^{2}$ & \multicolumn{2}{c}{ Increase from No-blow to blow } \\
\hline & CFU/sample $^{3}$ & $(\log \text { CFU/sample })^{4}$ & CFU/sample & $(\%)^{6}$ \\
Mean & $183^{\mathrm{b}}(2.2)^{\mathrm{b}}$ & $2889^{\mathrm{a}}\left(3.5^{\mathrm{a}}\right)$ & 2706 & 1479 \\
Median & $150(2.2)$ & $600(2.8)$ & 450 & 300 \\
Maximum & $300(2.5)$ & $37,450(4.6)$ & 37150 & 12383 \\
Standard deviation & $112(2.1)$ & $6620(3.8)$ & 6508 & 5811 \\
\hline
\end{tabular}

${ }^{1}$ No-blow $=$ cake icing not exposed to blowing out candles

${ }^{2}$ Blow $=$ cake icing exposed to blowing out candles 
${ }^{3}$ CFU/sample $=$ colony forming units per cake icing sample. $N=33$.

${ }^{4}$ Log CFUsample $=\log _{10}$ of colony forming units per cake icing sample

${ }^{5} \mathrm{CFU} /$ sample Increase $=\mathrm{CFU} /$ sample from samples blow on $-\mathrm{CFU} /$ sample from samples not blown on

${ }^{6} \%$ Increase $=\frac{(\text { CFU/sample from samples blow on }- \text { CFU/sample from samples not blown on })}{\text { CFU/sample from samples not blown on })} \times 100$

${ }^{\mathrm{a}, \mathrm{b}}$ means with different superscripts are significantly different $(\mathrm{p} \leq 0.0001)$.

\section{Acknowledgments}

This research was supported by the Creative Inquiry Program at Clemson University. Technical Contribution No. 6547 of the Clemson University Experiment Station.

\section{References}

Brankston, G., Gitterman, L., Hirji, Z., Lemieux, C., \& Gardam, M. (2007). Transmission of influenza A in human beings. The Lancet Infectious Diseases, 7, 257-265. https://doi.org/10.1016/S1473-3099(07)70029-4

Bright, K. R., Boone, S. A., \& Gerba, C. P. (2010). Occurrence of Bacteria and Viruses on Elementary Classroom Surfaces and the Potential Role of Classroom Hygiene in the Spread of Infectious Diseases. Journal of School Nursing, 26(1), 33-42. https://doi.org/10.1177/1059840509354383

Chao, C. Y. H., Wan, M. P., Morawska, L., Johnson, G. R., Ristovski, Z. D., ... Katoshevski, D. (2009). Characterization of expiration air jets and droplet size distributions immediately at the mouth opening. $J$ Aerosol Sci., 40(2), 122-133. https://doi.org/10.1016/j.jaerosci.2008.10.003

Couch, R., Knight, V., Gerone, P., Cate, T., \& Douglas, R. (1969). Factors influencing response of volunteers to inoculation with Coxsackie virus A type 21. American Review of Respiratory Disease, 99, 24-30. http://www.atsjournals.org/doi/abs/10.1164/arrd.1969.99.1.24\#readcube-epdf

Douwes, J., Thorne, P., Pearce, N., \& Heederik, D. (2003). Bioaerosol health effects and exposure assessment: Progress and prospects. Annals of Occupationanl Hygiene, 3, 187-200. https://doi.org/10.1093/annhyg/meg032

Duguid, J. P. (1946). The size and the duration of air-carriage of respiratory droplets and droplet nuclei. Epidemiology and Infection, 44(6), 471-479 https://doi.org/10.1017/S0022172400019288

Fabian, P., McDevitt, J. J., DeHaan, W. H., Fung, R. O. P., Cowling, B. J., Chan, K. H., Leung, G. M., \& Milton, D. K. Influenza virus in human exhaled breath: an observational study. PLoS ONE, 3, e2691. https://doi.org/10.1371/journal.pone.0002691

Fennelly, K. P., Martyny, J. W., Fulton, K. E., Orme, I. M., Cave, D. M., \& Heifets, L. B. et al. (2004). Cough-generated aerosols of Mycobacterium tuberculosis: a new method to study infectiousness. American Journal of Respiratory and Critical Care Medicine, 169(5), 604-609. http://dx/doi.org/10.1164/rccm.200308-11010C

Flugge, C. (1899). Die Verbreitung der Phthise durch staubförmiges Sputum und durch beim Husten verspritzte Tröpfchen. Zeitschrift fur Hygiene und Infektionskrankheiten, 30(1), 107-124. http://dx/.doi.org/10.1007/BF02198683

Frey, A. (1753) A True and Authentic Account of Andrwe Frey. https://books.google.com/books?id=VIoUAAAAQAAJ\&pg=PA15\&hl=en\#v=onepage\&q\&f=false

Hamburger, M. (1944). Studies on the transmission of hemolytic Streptococcus infections: I Cross infection in army hospital wards. Journal of Infectious Diseases, 75(1), 58-70. https://doi.org/10.1093/infdis/75.1.58

Houk, V. N. (1980) Spread of tuberculosis via recirculated air in a naval vessel: the Byrd study. Annals of the New York Academy of Sciences, 353, 10-24. https://doi.org/10.1111/j.1749-6632.1980.tb18901.x

Hutchison, R. F. (1901). Die Verbreitung von Keimen durch gewöhnliche Luftströme. Zeitschrift fur Hygiene und Infektionskrankheiten, 36(1), 223-253. https://doi.org/ 10.1007/BF02141226

Huynh, K. N., Oliver, B. G., Stelzer, S., Rawlinson, W. D., \& Tovey, E. R. (2008). A new method for sampling and detection of exhaled respiratory virus aerosols. Clin Infect Dis, 46, 93-95.

https://doi.org/10.1086/523000 
Knight, V. (1973). Airborne transmission and pulmonary deposition of respiratory viruses. In: Hers JF, Winkles KC, editors. Airborne transmission and airborne infections. VIth Int. Symp. on Aerobiology. New York, NY: Wiley, pp. 175-182.

Lange, B., \& Nowoselsky, W. (1925). Experimentelle Untersuchungen über die Bedeutung der Staubinfektion bei der Tuberkulose. Medical Microbiology and Immunology, 104(1-2), 286-307. https://doi.org/10.1007/BF02175004

Lindsley, W. G., Blachere, F. M., Thewlis, R. E., Vishnu, A., Davis, K. A., Cao, G., \& Palmer, J. E. (2010) Measurements of airborne influenza virus in aerosol particles from human coughs. PLoS ONE 5: e15100. https://doi.org/10.1371/journal.pone.0015100 .

Loosli, C., Hertweck, M., \& Hockwald, R. (1970) Airborne influenza PR8-A virus infections in actively immunized mice. Arch Envir Hlth, 21, 332-346. https://doi.org/10.1080/00039896.1970.10667248

Madigan, M. T., Martinko, J. M., Dunlap, P. V., \& Clark, D. P. (2009). Brock: Biology of Microorganisms, $12^{\text {th }}$ ed. San Francisco: Pearson. 1061 p.

Obeng, C. S. (2008). Personal Cleanliness Activities in Preschool Classrooms. Early Childhood Education Journal, 36, 93-99. http:// doi.org/10.1007/s.10643-008.0253.4.

Qian, J., Hospodsky, D., Yamamoto, N., Nazaroff, W. W., \& Peccia, J. (2012) Sizeresolved emission rates of airborne bacteria and fungi in an occupied classroom. Indoor Air, http://doi.org/10.1111/j.1600-0668.2012.00769 .

SAS (2010). Statistical Analysis Institute User's Guide :Basics, 9.1 ed., SAS Institute Inc. Cary, NC.

Stelzer-Braid, S., Oliver, B. G., Blazey, A. J., Argent, E., Newsome, T. P., Rawlinson, W. D., \& Tovey, E. R. (2009). Exhalation of respiratory viruses by breathing, coughing, and talking. Journal of Medical Virology, 81, 1674-1679. http://doi.org/10.1002/jmv.21556

Strausz, W. (1922). Versuche über beim Sprechen verschleuderte Tröpfchen. Zeitschrift fur Hygiene und Infektionskrankheiten, 96(1), 27-47 https://doi.org/ 10.1007/BF02183834

Tellier, R. (2009) Aerosol transmission of influeza A virus: a review of new studies Journal of the Royal Society Interface. Published online 1-8. http://doi.org/10.1098/rsif.2009.0302.focus

Wan, G. H., Wu, C. L., Chen, Y. F., Huang, S. H., Wang, Y. L., \& Chen, C. W. (2014) Particle Size Concentration Distribution and Influences on Exhaled Breath Particles in Mechanically Ventilated Patients. PLoS ONE, 9(1), e87088. http://doi:10.1371/journal.pone.0087088

Weber, T. P., \& Stilianakis, N. I. (2008) Inactivation of influenza A viruses in the environment and modes of transmission: a critical review. Journal of Infection, 57, 361-373. https://doi.org/10.1016/j.jinf.2008.08.013

Wein, L. M., \& Atkinson, M. P. (2009) Assessing infection control measures for pandemic influenza. Risk Analysis, 29, 949-962. http://doi.org/10.1111/j.1539-6924.2009.01232.x

Winslow, C. E. A. (1910).An investigation of the extent of the bacterial pollution of the atmosphere by mouth spray. The Journal of Infectious Diseases, 7(1), 17-37. http://dx/doi.org/ 10.1093/infdis/7.1.17

Xu, Z., Wu, Y., Shen, F., Chen, Q., Tan, M., \& Yao, M. (2011) Bioaerosol science, technology, and engineering: past, present, and future. Aerosol Science and Technology, 45, 1337-1349. https://doi.org/10.1080/02786826.2011.593591

Xu, Z., Shen, F., Li, X, Wu, Y., Chen, Q., Jie, X., \& Yao, M. (2012). Molecular and microscopic analysis of bacteria and viruses in exhaled breath collected using a simple impaction and condensing method. Plos One, 7(7), 1-8. Published online www.plosone.org

Yu, I. T., Li, Y., Wong, T. W., Tam, W., Phil, M., Chan, A. T., Lee, J., Leung, D., \& Ho, T. (2004) Evidence of airborne transmission of the severe acute respiratory syndrome virus. New England Journal of Medicine, 351, 1731-1739. https://doi.org/10.1056/NEJMoa032867

\section{Copyrights}

Copyright for this article is retained by the author(s), with first publication rights granted to the journal.

This is an open-access article distributed under the terms and conditions of the Creative Commons Attribution license (http://creativecommons.org/licenses/by/3.0/). 